\title{
Diurnal Changes in Plasma Lipoproteins in Normal Subjects and Diabetics
}

\author{
R. W. Simpson 1,3, R. D. Carter ${ }^{1}$, R. A. Moore ${ }^{2}$, and W. A. F. Penfold ${ }^{2}$ \\ ${ }^{1}$ Department of The Regius Professor of Medicine and ${ }^{2}$ Nuffield Department of Clinical Biochemistry, \\ Radcliffe Infirmary, Oxford, England
}

\begin{abstract}
Summary. Significant diurnal variations in levels of total plasma cholesterol, HDL cholesterol and LDL cholesterol were found in the majority of 12 normals, 13 maturity onset and 14 insulin requiring diabetics. The variations in total cholesterol and its lipoprotein subfraction were more marked in diabetics. These variations were not correlated in either diabetic group with glucose control as assessed by the level of glycosylated haemoglobin. The significance of the diurnal changes in total plasma cholesterol and the lipoprotein subfractions in relation to arteriovascular disease is discussed.
\end{abstract}

Key words: Diurnal changes, total cholesterol, lipoprotein cholesterol, diabetes mellitus, normal subjects.

Increased total cholesterol [1] and more recently decreasing high density lipoprotein (HDL) cholesterol [2-7] have been found to be associated with arteriovascular disease in non-diabetics. The situation for diabetics is less certain although these patients are known to have disturbed lipid metabolism $[8,9]$, and an increased incidence of cardiovascular disease [10]. In particular, the close association between low HDL cholesterol and arteriovascular disease is not as straightforward in diabetics [11]. Many of these studies however, have been based on single, sometimes non-fasting blood samples taken at different times during the day and there is now clear evidence that a single fasting sample may be an insensitive guide to disordered metabolism of a number of metabolites $[12,13]$ and hormones $[14$, $15]$.

\footnotetext{
${ }^{3}$ Present address: Endocrine Registrar, Prince Henry's Hospital, St. Kilda Rd., Melboume 3004, Australia
}

Thus a better understanding of the role of cholesterol and the various lipoprotein fractions in disease requires a knowledge of the diurnal levels. Tracer studies have indicated that the lipoprotein apoproteins have a half life measured in days [16-18] and that total cholesterol in non-diabetics also has a half life of several days [19]. However, it is not possible to extrapolate from these findings to diurnal changes and a number of studies examining these patterns for total cholesterol in non diabetics [20-24] have produced conflicting results. The object of this study is to determine whether diurnal changes exist for total cholesterol and its lipoprotein subfractions in normal and diabetic subjects.

\section{Patients and Methods}

The details of the subjects are shown in Table 1. All insulin dependent patients were on twice daily regimes (12 on Ultralente and twice daily Soluble insulin and 2 on twice daily Isophane and Soluble insulin). One maturity onset diabetic was on diet alone and 13 on Sulphonylureas. All patients were considered to be under reasonable diabetic control on the basis of minimal glycosuria. All the patients gave their informed consent and the study was approved by the local Ethical Committee.

Subjects were admitted for a 24-hour study starting at 17.30 hours. During this time the patients received their usual diet, which contained typical contents of carbohydrate $(45 \%)$, protein $(18 \%)$ and fat $(37 \%$ of total calories). The total calories varied between the different diabetics according to age and obesity and was not recorded. The normal subjects received the normal hospital diet which varied from day-to-day, but on average contained $40-50 \%$ carbohydrate, about $15-20 \%$ protein and $35-45 \%$ fat. They all received their meals at set times (dinner 18.10, breakfast 08.30 and lunch at 12.30 ) and where appropriate their insulin (17.45 and 08.15) or oral medication (17.45 and 08.15 depending on tpye of sulphonylurea). During the day the subjects were dressed and encouraged to exercise normally.

Blood samples were taken at half to two hourly intervals through an indwelling Teflon cannula inserted into a forearm vein under local anaesthetic. Blood samples were placed in EDTA 
Table 1. Details of subjects

\begin{tabular}{lccccc}
\hline Subjects & Male & Female & Age (years) & $\begin{array}{l}\text { Weight \% ideal } \\
\text { body weight }\end{array}$ & Duration of disease (years) \\
\hline $\begin{array}{l}\text { Normals } \\
\begin{array}{l}\text { Maturity onset } \\
\text { diabetics }\end{array}\end{array}$ & 7 & 5 & $39 \pm 3$ & $112.4 \pm 4.5$ & - \\
$\begin{array}{l}\text { Insulin requiring } \\
\text { diabetics }\end{array}$ & 10 & 3 & $44 \pm 3$ & $113.2 \pm 3.7$ & $4 \pm 1$ \\
\hline
\end{tabular}

Results expressed as mean $\pm \mathrm{SEM}$

Table 2. Quality control values

\begin{tabular}{|c|c|c|c|c|}
\hline & \multicolumn{2}{|l|}{ Intra-assay } & \multicolumn{2}{|l|}{ Inter-assay } \\
\hline & $\begin{array}{l}\text { Coefficient of } \\
\text { variation }(\%)\end{array}$ & $\begin{array}{l}\text { Mean level } \\
(\mathrm{mmol} / \mathrm{l})\end{array}$ & $\begin{array}{l}\text { Coefficient of } \\
\text { variation }(\%)\end{array}$ & $\begin{array}{l}\text { Mean level } \\
(\mathrm{mmol} / \mathrm{l})\end{array}$ \\
\hline Total plasma & & & & \\
\hline Cholesterol & 1.0 & 6.3 & 4.0 & 5.8 \\
\hline HDL Cholesterol & 2.4 & 1.7 & 10.4 & 1.4 \\
\hline LDL cholesterol & 1.9 & 4.4 & - & - \\
\hline
\end{tabular}

Intra-assay coefficients of variation were determined by assaying 3 plasma pools each, 20 times in one assay. Inter-assay coefficient of variation were determined from one plasma pool stored in aliquots at $-20^{\circ} \mathrm{C}$ and assayed over a 3 -month period

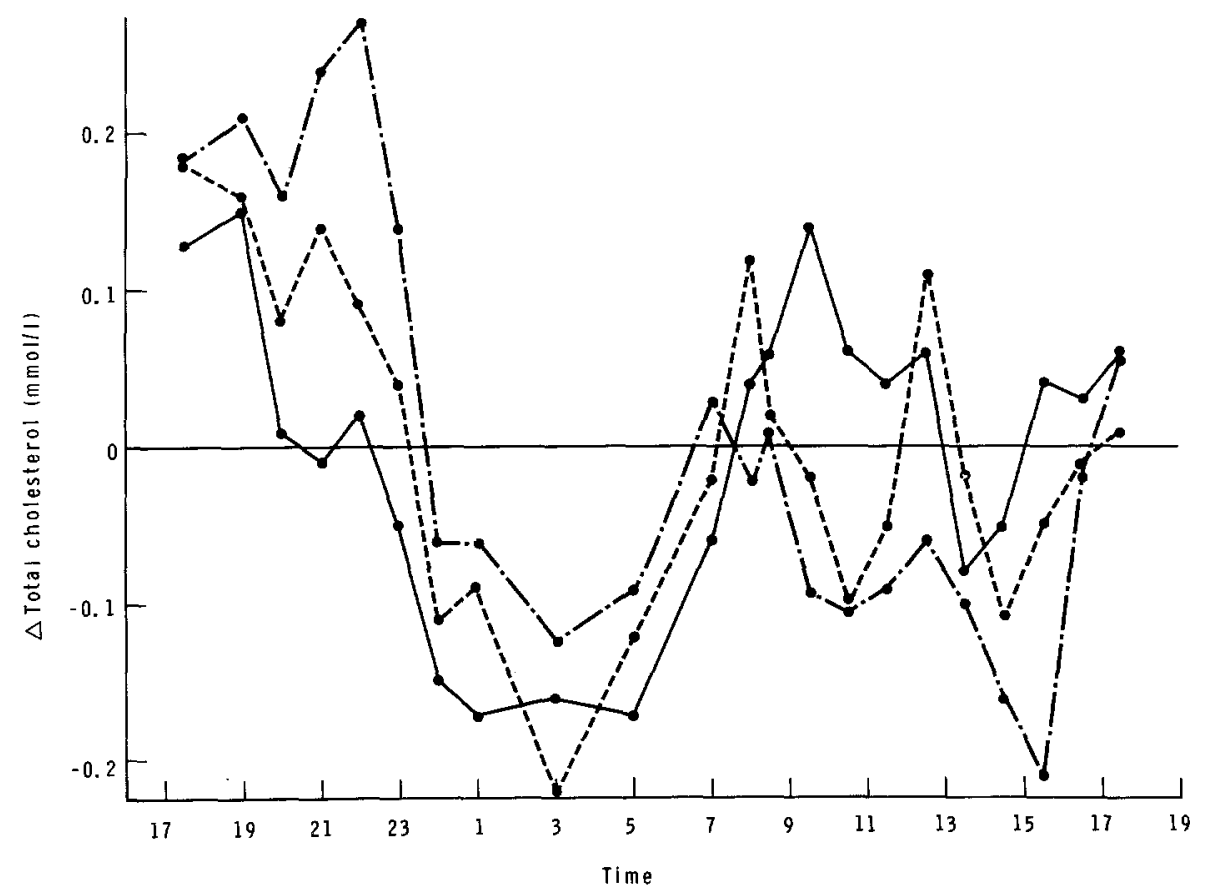

Fig. 1. The difference between an individual result and the average 24hour total cholesterol level $(\triangle$ Total cholesterol) is plotted for each group of subjects over 24-hours. 0 Normal $(\mathrm{n}=12)$ $O$-----O Maturity onset diabetic $(\mathrm{n}=13) ; \mathrm{O}-\ldots-\ldots$ Insulin requiring diabetic $(\mathrm{n}=14)$

tubes and after immediate separation the plasma was stored at $4{ }^{\circ} \mathrm{C}$ for not more than 48-hours before assay.

All cholesterol measurements were made on a Technicon Autoanalyser II by the Liebermann-Burchard reaction [25] using unextracted samples: a standard curve was prepared by diluting freeze-dried control serum (Versatol Hi, General Diagnostics Ltd.) over the range 0.4-6.0 mmol/l. Samples for total cholesterol were diluted $1: 1$ with $0.154-\mathrm{M}-\mathrm{NaCl}$ before analysis. HDLcholesterol was measured in the supernatant obtained by precipitation of the low-density lipoprotein (LDL) and very low density (VLDL) with heparin and manganese chloride [26] (final concen- tration $2.2 \mathrm{~g} / 1$ and $83.0 \mathrm{mmol} / 1$ respectively). LDL and HDLcholesterol were measured in the supernatant obtained after precipitation of VLDL by sodium dodecyl sulphate [27] and the LDL cholesterol obtained by difference.

All the samples from any one patient were prepared together and measured in a single autoanalyser run. The mean intra-assay coefficients of variation derived from three studies in which 20 aliquots of pooled plasma were assayed consecutively on one day are shown in Table 2 . The inter-assay coefficients of variation from deep-frozen plasma pools assayed over a 3 -month period are also shown. 
Table 3. Mean of the average 24 hour levels of total cholesterol, HDL cholesterol and LDL cholesterol for normals, maturity onset and insulin requiring diabetics

\begin{tabular}{llll}
\hline $\begin{array}{l}\text { Mean of average } \\
24 \text { hour level }\end{array}$ & $\begin{array}{l}\text { Normal } \\
(\mathrm{n}=12)\end{array}$ & $\begin{array}{l}\text { Maturity onset } \\
\text { diabetics } \\
(\mathrm{n}=13)\end{array}$ & $\begin{array}{l}\text { Insulin } \\
\text { requiring } \\
\text { diabetics } \\
(\mathrm{n}=14)\end{array}$
\end{tabular}

\begin{tabular}{llll}
\hline $\begin{array}{l}\text { Total cholesterol } \\
\mathrm{mmol} / \mathrm{l}\end{array}$ & $4.70 \pm 0.2$ & $5.00 \pm 0.4$ & $4.70 \pm 0.2$ \\
$\begin{array}{l}\mathrm{HDL} \text { cholesterol } \\
\mathrm{mmol} / \mathrm{l}\end{array}$ & $1.46 \pm 0.08$ & $1.53 \pm 0.12$ & $1.75 \pm 0.09^{\mathrm{a}}$ \\
$\begin{array}{l}\mathrm{LDL} \mathrm{cholesterol} \\
\mathrm{mmol} / \mathrm{l}\end{array}$ & $2.73 \pm 0.23$ & $2.73 \pm 0.39$ & $2.97 \pm 0.22$ \\
\hline
\end{tabular}

a " $\mathrm{t}$ " test (comparing against normal), $\mathrm{p}<0.01$
Table 5. Analysis of variance for 24 hour profile of total cholesterol, HDL cholesterol and LDL cholesterol for normals, maturity onset and insulin requiring diabetics

\begin{tabular}{lllll}
\hline & \multicolumn{5}{c}{ Significance level } \\
\hline & & $\mathrm{NS}$ & $\mathrm{p}<0.05$ & $\mathrm{p}<0.01$ \\
\hline Total cholesterol & $\mathrm{N}(\mathrm{n}=12)$ & 0 & $1 / 12$ & $11 / 12$ \\
& MOD & 0 & $2 / 13$ & $11 / 13$ \\
& $(\mathrm{n}=13$ & & & \\
& Insulin & & & \\
& $(\mathrm{n}=14)$ & $1 / 14$ & 0 & $13 / 14$ \\
HDL cholesterol & $\mathrm{N}(\mathrm{n}=12)$ & $1 / 12$ & $2 / 12$ & $9 / 12$ \\
& MOD & $1 / 13$ & $2 / 13$ & $10 / 13$ \\
& $(\mathrm{n}=13)$ & & & \\
& Insulin & & & \\
& $(\mathrm{n}=14)$ & 0 & 0 & $14 / 14$ \\
& $\mathrm{~N}(\mathrm{n}=12)$ & $5 / 12$ & $2 / 12$ & $5 / 12$ \\
& MOD & 0 & $1 / 13$ & $12 / 13$ \\
& $(\mathrm{n}=13)$ & & & \\
& Insulin & & & \\
& $(\mathrm{n}=12)$ & 0 & $1 / 12$ & $11 / 12$ \\
& & & &
\end{tabular}

Table 4. The mean and range of difference between nadir and peak value for total cholesterol and its subfractions for normals, maturity onset and insulin requiring diabetics

\begin{tabular}{llll}
\hline & Normal & Maturity onset diabetics & Insulin requiring diabetics \\
\hline $\begin{array}{l}\text { Total cholesterol } \\
\text { Mean (range) mmol/1 }\end{array}$ & $0.7(0.4-0.9)$ & $0.8(0.4-1.9)$ & $0.9(0.3-1.6)$ \\
$\begin{array}{l}\text { HDL cholesterol } \\
\text { Mean (range) } \mathrm{mmol} / 1\end{array}$ & $0.34(0.18-0.66)$ & $0.37(0.18-1.04)$ & $0.6(0.33-1.80)$ \\
LDL cholesterol & $0.54(0.29-1.15)$ & $1.00(0.45-1.87)$ & $1.13(0.52-2.4)$ \\
\hline
\end{tabular}

The results are expressed as either the mean \pm standard error of the mean of the average 24-hour level or mean change about the average 24-hour level. To test the significance of the variations in the 24-hour profiles the method of analysis of variance was employed:

$F$ ratio $=\frac{\text { variance of the } 23 \text { samples from each patient }}{\text { mean variance derived from } 3 \text { assays where } 20 \text { ali- }}$ quots of pooled plasma were assayed consecutively.

Comparisons between the mean $\mathrm{F}$ ratios derived from each subject group were made using the Mann-Whitney $U$ test.

Glycosylated haemoglobin was estimated by cation exchange resin chromatography [28].

\section{Results}

\section{Total Cholesterol}

The mean cholesterol profiles for all three groups of subjects are shown in Figure 1 and the mean of the average 24-hour total cholesterol levels in Table 3. The normal subjects ( 11 out of 12 ) reached a nadir over night (mean $4.4 \pm 0.2 \mathrm{mmol} / \mathrm{l}$ ) and a peak during the day or early evening (mean $5.0 \pm 0.2 \mathrm{mmol} /$ 1). There was also a tendency for the maturity-onset diabetics to show this pattern ( 8 out of 13 ) with a mean nadir of $4.5 \pm 0.3 \mathrm{mmol} / \mathrm{l}$ and a mean peak of $5.4 \pm 0.4 \mathrm{mmol} / \mathrm{l}$. The insulin requiring patients $(12$ out of 14) reached a peak (mean $4.3 \pm 0.2 \mathrm{mmol} / \mathrm{l}$ ) during the early morning or day. The mean and range of differences between the peak and nadir for all groups are shown in Table 4. As Table 5 indicates for the analysis of variance, all subjects (except one insulin requiring diabetic) showed a significant variation in the level of total cholesterol throughout the 24hours. Although the mean $F$ values of both diabetic groups are greater than that for normals only the difference between normals and insulin requiring diabetics was significant (Table 6).

In order to see if there was an association between variability and the level of cholesterol the correlation between the $F$ ratio and the average level of total cholesterol was estimated. The correlation for normals $(p=0.06)$ was not significant. However, the correlation for both maturity onset and insulin requiring diabetics was strongly significant $(\mathrm{r}=0.73$; $\mathrm{p}<0.01$ and $\mathrm{r}=0.64 ; \mathrm{p}<0.01$ respectively).

Although there was no one time during the day when the plasma cholesterol level for all subjects accurately reflected the average 24-hour level, the 


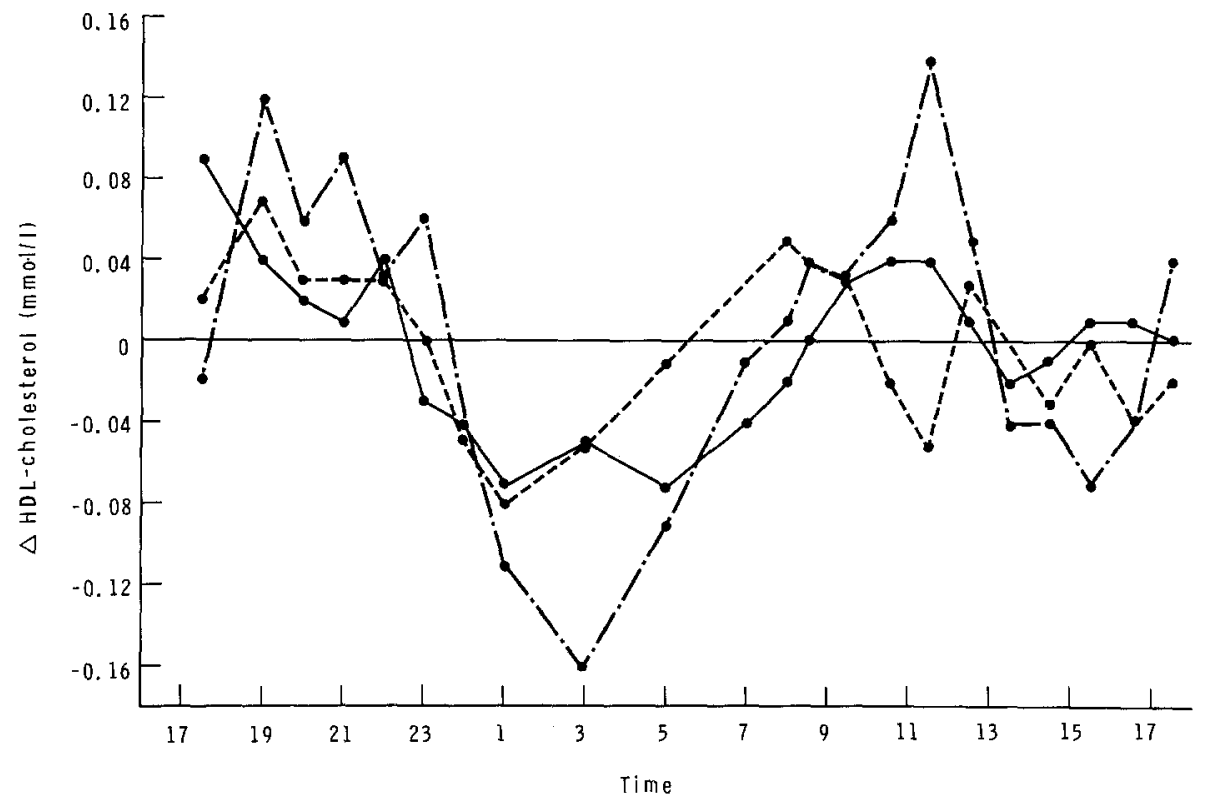

Fig. 2. The difference between an individual result and the average 24hour HDL-cholesterol ( $\triangle \mathrm{HDL}$ cholesterol) is plotted for each group of subjects over 24-hours. $\mathrm{O}$ Normal $(\mathrm{n}=12)$; O--.--.. Maturity onset diabetic $(n=13)$; O__ _... Insulin requiring diabetic $(n=14)$
Table 6. Mean F ratios for total cholesterol and the subfractions in normals and diabetics

\begin{tabular}{lrrr}
\hline & Normals & $\begin{array}{l}\text { Maturity onset } \\
\text { diabetics }\end{array}$ & $\begin{array}{l}\text { Insulin } \\
\text { requiring } \\
\text { diabetics }\end{array}$ \\
\hline Total cholesterol & & & \\
Mean \pm SEM & $8.6 \pm 1.2$ & $12.8 \pm 3.2$ & $15.6 \pm 2.8^{\mathrm{a}}$ \\
HDL cholesterol & $6.2 \pm 1.3$ & $9.7 \pm 4.1$ & $18.1 \pm 6.6^{\mathrm{b}}$ \\
LDL cholesterol & $3.0 \pm 0.6$ & $17.1 \pm 6.2$ & $13.6 \pm 4.3^{\mathrm{b}}$
\end{tabular}

Mann - Whitney $U$ test: ${ }^{a}$ (Comparing against normals), $p<0.05$; ${ }^{b} \mathrm{p}<0.002$

fasting sample (08.00) for all, with the exception of one maturity onset patient, was $0.3 \mathrm{mmol} / 1$ or less from the average value.

\section{HDL-Cholesterol}

The mean 24-hour HDL cholesterol profiles for the three groups are illustrated in Figure 2 and the mean of the average 24-hour levels in Table 3. Unlike total cholesterol, the mean of the average 24-hour HDLcholesterol level for normals differs significantly from that of the insulin requiring patients. All three groups showed a nadir of HDL-cholesterol levels in the morning. This was seen for 10 out of 12 normal, 8 out of 12 maturity onset and 12 out of 14 insulin requiring patients. The mean differences and range between peak and nadir for normal subjects and both patient groups are shown in Table 4. Table 5 illustrates that the diurnal variation was significant for all but one normal and one maturity onset diabetic. The mean $\mathrm{F}$ ratio was greater for both patient groups than for normals but again only normals and insulin requiring diabetics differed significantly (Table 6).
There was no correlation between the average 24hour HDL-cholesterol level and the F ratio in either of the diabetic or normal groups. Again there was no one time during the day when a single sample reflected accurately the average 24-hour level of HDL-cholesterol for any group. However, the fasting sample at 08.00 hours was within $0.2 \mathrm{mmol} / \mathrm{l}$ of the mean 24 hour level for all patients with the exception of one maturity onset diabetic.

\section{LDL-Cholesterol}

The mean of the average 24-hour levels are shown in Table 3. Unlike the total and HDL-cholesterol levels, no consistent pattern of change in values was observed for any of the groups of subjects. The analysis of variance (Table 5) showed that a significant diurnal variation in LDL-cholesterol occurred in 7 out of 12 normals and all the maturity onset and insulin requiring patients.

The difference between the highest and lowest values for all groups are shown in Table 4 . The mean $F$ ratio of both diabetic groups was significantly larger than that of normals (Table 6). There was no significant correlation between the average 24 -hour level of LDL-cholesterol and the F ratio for normals $(\mathrm{r}=0.6, \mathrm{p}=\mathrm{n}$. $\mathrm{s}$.) or maturity onset patients $(\mathrm{r}=$ $0.47, \mathrm{p}=\mathrm{n}$. s.) but a significant correlation did exist for insulin requiring patients $(\mathrm{r}=0.64, \mathrm{p}<0.03$ ). The 08.00 hours LDL-cholesterol level for all subjects with the exception of 2 maturity-onset patients was within $0.3 \mathrm{mmol} / 1$ of the average 24 -hour level.

Small, in some cases significant, changes in total cholesterol and its lipoprotein subfractions occurred after several meals in normal subjects and both diabetic age groups. Neither diabetic group showed 
any significant correlations between the percentage of glycosylated haemoglobin and the $\mathrm{F}$ ratios for total cholesterol or the lipoprotein components.

\section{Discussion}

An individual's lipoprotein cholesterol status is traditionally assessed by a single fasting but sometimes non-fasting, random sample. As the role of lipoprotein cholesterol in the genesis of arterial disease may, at least in part, be a function of duration of exposure to a given plasma lipid level, the assessment of lipoprotein status by random sampling assumes the absence of a significant diurnal variation in plasma levels. We have shown here that a diurnal variation does exist for total cholesterol, HDL-cholesterol and LDL-cholesterol in most subjects.

The significant variation observed in total cholesterol in non-diabetics is consistent with some previous reports $[20,22,23]$. Although several earlier authors came to differing conclusions, the mean $\mathrm{F}$ ratios estimated from the published data $[22,23,24]$ are highly significant. However, this variation represents only a small percentage change about the mean level and therefore a random sample in this group provides a reasonable estimate of the mean daily level $[20,24,25]$. As the daily variation is increased in diabetics, particularly insulin requiring patients, and diabetics, unlike normals, show a strong correlation between the average daily value of total cholesterol and variation in levels, single, random total cholesterol estimations in these patients are a less reliable index of the average level. This observation may partly explain the apparent lack of an association between arteriovascular disease and increased total cholesterol levels in diabetics.

The difficulty of assessing lipoprotein status from a random sample is more apparent for HDL-cholesterol because of the significant diurnal variation found for all 3 groups of subjects. It is of interest that the differences in HDL-cholesterol levels between subjects with and without arteriovascular disease in 2 studies [6,7], were in the order of 0.2 to $0.4 \mathrm{mmol} / 1$. This is well within the range of diurnal change observed for all three groups. The more marked variability in HDL-cholesterol levels in diabetics again highlights the increased difficulty of assessing their status from a random sample. Again, the difficulty experienced by a number of workers attempting to show an association between low HDL-cholesterol levels and arteriovascular disease in diabetics could result from a failure to consider the diurnal changes. It is interesting that unlike total cholesterol in both diabetic groups, variability in HDL-cholesterol levels is not related to the mean 24-hour value.

LDL-cholesterol has not been found to be independently associated with arteriovascular disease in non-diabetics, although there does appear to be an association in diabetic men [11]. However, this cholesterol fraction does show a significant diurnal variation which is more marked in diabetics. Clearly this must be taken into account in future studies.

Unfortunately, the precipitation techniques do not reliably estimate VLDL-cholesterol (co-efficients of variations of $7 \%$ and $27 \%$ at mean levels of $1.0 \mathrm{mmol} / 1$ and $0.3 \mathrm{mmol} / 1$ respectively) and therefore we were unable to study diurnal changes in this lipoprotein fraction.

The changes observed in total cholesterol and lipoprotein levels following some meals are not consistent with previous reports $[6,21,29,30]$ in nondiabetics. Although the cholesterol fractions may change after meals in diabetics, the post-prandial variation observed in the present study could not be separated from the diurnal changes.

The reasons for the diurnal pattern in total cholesterol and its subfractions are uncertain although cholesterol is thought to transfer between HDL and VLDL [31] and in the presence of cholesterol movement between circulating lipoprotein subfractions diurnal changes are perhaps not unexpected.

Several studies $[32,33]$ have shown that prolonged venous occlusion produces haemoconcentration and an increase in total cholesterol. In the present study the majority of blood samples were taken free flowing. When occlusion was required this was kept to a minimum and in most cases it lasted for less than 2 minutes.

There is no evidence in the present work as to the cause of the much greater degree of diurnal variation of the lipoprotein subfractions found in the diabetic subjects, and especially insulin requiring diabetics. There was little difference between the two diabetic groups in terms of the percentage contribution of carbohydrate, protein and fat in the diet, and the pattern was similar to the meals which the normal subjects received on the ward. There was no information regarding the total in-take of calories by each group. Even if the lipid differences were attributable to diet this does not affect the observation that in everyday life the three groups are different. Certainly, the degree of diurnal variation seems to have no direct involvement with diabetic control, since in no case was there any relationship found between the variability of any subfractions in any group and the amount of glycosylated haemoglobin present. It has been suggested [8] that the greater risk of atherosclerosis in diabetes is associated with an aetiology other than lipid changes but this is difficult to support while the effect of the greater variation of the lipoproteins (as opposed to their cause) is unknown. Thus a knowledge of the diurnal variation of lipoproteins may be of value in interpreting the association 
between lipid levels and the atherosclerotic process in diabetes.

Acknowledgements. This work was supported by the Oxford Area Research Committee, Napp Laboratories Limited, ICI and the Flora Information Service.

We wish to thank Drs. J. I. Mann, R.C. Turner and T. D. R. Hockaday for their help and advice and Mrs. Maggy Beeton for her excelient nursing assistance.

\section{References}

1. Kannell, W. B., Castelli, W. P., Gordon, T., McNamara, P. M.: Serum Cholesterol, lipoproteins, and the risk of coronary heart disease. Ann. Intern. Med. 74, 1-12 (1971)

2. Nikkilä, E.: Studies on the lipoprotein relationships in normal and pathological sera and the effect of heparin on serum lipoproteins. Scand. J. Clin. Lab. Invest. 5 [Suppl. 8], 1-101 (1953)

3. Lewis, B., Chait, A., Oakley, C. M. O., Wootton, I. D. P., Krikler, D.M., Onitiri, A., Sigurdsson, G., February, A.: Serum lipoprotein abnormalities in patients with ischaemic heart disease: Comparison with a control population. Br. Med. J. 1974 III, $489-493$

4. Castelli, W. P., Doyle, J. T., Gordon, T., Hames, C., Hulley, S. B., Kagan, A., McGee, D., Vicic, W. J., Zukel, W. J.: HDLCholesterol levels in coronary heart disease: A co-operative lipoprotein phenotyping study. Circulation 52 [Suppl. II], 97 (1975)

5. Rehoads, G. G., Gulbrandsen, C. L., Kagan, A.: Serum lipoproteins and coronary heart disease in a population study of Hawaii Japanese men. N. Engl. J. Med. 294, 293-298 (1976)

6. Miller, N.E., Thelle, D.S., Førde, O.H., Mjøs, O. D.: The Tromso Heart study. High density lipoprotein and coronary heart disease. A prospective case - control study. Lancet 1977 I, 965-967

7. Rössenr, S., Kjellin, K. G., Mettinger, K. L., Sidén, A., Söderström, C. E.: Normal serum-cholesterol but low HDL-cholesterol concentration in young patients with ischaemic cerebrovascular disease. Lancet 1978 I, 577-579

8. Garcia, M. J., McNamara, P. M., Gordon, T., Kannell, W. B.: Morbidity and mortality in diabetics in the Framingham population. Diabetes 23, 105-111 (1974)

9. Simpson, R. W., Mann, J. I., Hockaday, T. D. R. H., Hockaday, J. M., Jelfs, R.: Lipid abnormalities in untreated maturityonset diabetics and the effect of treatment. Diabetologia 16, 101-106 (1979)

10. Jarrett, R. J., Keen, H.: Diabetes and atherosclerosis. In: Complications of diabetes. Keen, H., Jarrett, R. J. (Eds.), p. 179-203. London: Edward Arnold Ltd. 1975

11. Reekless, J. P. D., Betteridge, D. J., Wu, P., Payne, B., Galton, D. J.: High density and low density lipoproteins and prevalence of vascular disease in diabetes mellitus. Br. Med. J. 1978 I, $883-886$

12. Rooth, G., Carlström, S.: Diurnal variations of blood glucose, 3 hydroxybutyrate, acetoacetate, plasma free fatty acids and glycerol in diabetics. Acta Med. Scand. 191, 559-563 (1972)

13. Carlströms, S.: Studies on fatty acid metabolism in diabetics during exercise. Acta Med. Scand. 181, 609-621 (1967)

14. Hansen, Aa. P.: Serum growth hormone patterns in female juvenile diabetics. J. Clin. Endocrinol. Metab. 36, 638-646 (1973)

15. Migeon, C. J., Tyler, F. H., Mahoney, J. P., Florentin, A. A., Castle, H., Bliss, E. L., Samuels, L. T.: The diumal variation of plasma levels and urinary excretion of 17-hydroxycorticosteroids in normal subjects, night workers and blind subjects. J. Clin. Endocrinol. Metab. 16, 622-633 (1956)

16. Gitlin, D., Cornwell, D. G., Nakasato, D., Oncley, J. L., Hughes, W. L., Janeway, C. A.: Studies on the metabolism of plasma proteins in the nephrotic syndrome. II. The lipoproteins. J. Clin. Invest. 37, 172-184 (1958)

17. Scanu, A., Hughes, W. L.: Further characterization of the human serum D 1.063-1.21, $\alpha_{1}$-lipoprotein. J. Clin. Invest. 41, $1681-1689$ (1962)

18. Blum, C. B., Levy, R. I., Eisenberg, S., Hall, M., Goebel, R. H., Berman, M.: High density lipoprotein metabolism in man. J. Clin. Invest. 60, 795-807 (1977)

19. Goodman, De W. S.: The in vivo turnover of individual cholesterol esters in human plasma lipoproteins. J. Clin. Invest. 43, 2026-2036 (1964)

20. Boyd, E. M.: Diurnal variations in plasma lipids. J. Biol. Chem. 110, 61-70 (1935)

21. Schapiro, W., Estes, E. H., Hilderman, H. L.: Diurnal variability of serum cholesterol at normal and reduced levels. J. Lab. Med. 54, 213-215 (1959)

22. Peterson, J. E., Wilcox, A. A., Haley, M. I., Keith, R. A.: Hourly variation in total serum cholesterol. Circulation 22, 247-253 (1960)

23. Page, I. H., Moinuddin, M.: Hourly variations in serum cholesterol. J. Atheroscler. Res. 2, 181-185 (1962)

24. Hollister, L. E., Wright, A.: Diurnal variation of serum lipids. J. Atheroscler. Res. 5, 445-450 (1965)

25. Huang, T. C., Chen, C. P., Wefler, V., Raftery, A.: A stable reagent for the Liebermann-Burchard reaction. Application for rapid serum cholesterol determination. Anal. Chem. 33, 1405-1407 (1961)

26. Burstein, M., Scholnick, H. R., Morfin, R.: Rapid method for the isolation of lipoproteins from human serum precipitation with polyanions. J. Lipid Res. 11, 583-595 (1970)

27. Ononogba, I. C., Lewis, B.: Lipoprotein fractionation by a precipiation method. A simple quantitative procedure. Clin. Chim. Acta 71, 397-402 (1976)

28. Kynoch, P. A. M., Lehmann, H.: Rapid estimation (21/2 hours) of glycosylated haemoglobin for routine purposes. Lancet 1977 II, 16

29. Havel, R. J.: Early effects of fat ingestion on lipids and lipoproteins of serum in man. J. Clin. Invest. 36, 848-854 (1957)

30. Havel, R. J.: Early effects of fasting and of carbohydrate ingestion on lipids and lipoproteins of serum in man. J. Clin. Invest. 36, 855-859 (1957)

31. Lewis, B.: Metabolism of plasma cholesterol. In: The hyperlipidaemias, clinical and laboratory practice, p. 93-119. Oxford: Blackwell Scientific Publications 1976

32. Koerselman, H. B., Lewis, B., Pilkington, T. R. E.: The effect of venous occlusion on the level of serum cholesterol. J. Atheroscler. Res. 1, 85-88 (1961)

33. Page, I. H., Moinuddin, M.: The effect of venous occlusion on serum cholesterol and total protein - A warning. Circulation 25, 651-652 (1962)

Received: February 7, 1979,

and in revised form: July 27,1979

Dr. R. A. Moore

Nuffield Department of Clinical Biochemistry

Radcliffe Infirmary

Oxford OX2 6HE

England 